\title{
Aplikasi Perhitungan Zakat Berbasis Android di Badan Amil Zakat Nasional (Baznas) Kabupaten Karanganyar
}

\author{
Anton Respati Pamungkas*1 ${ }^{*}$ Kristono $^{2}$, Eko Budi Setiarso ${ }^{3}$ \\ ${ }^{1,2,3}$ Program Studi Sistem Informasi, STMIK AUB Surakarta, Indonesia \\ e-mail: *1anton18@stmik-aub.ac.id, ${ }^{2}$ kristono@stmik-aub.ac.id
}

\begin{abstract}
Abstrak
Badan Amil Zakat Nasional (BAZNAS) Kabupaten Karanganyar dalam mengumpulkan zakat dari masyarakat membentuk Unit Pengumpul Zakat (UPZ) dan juru pungut. Permasalahan yang dihadapi adalahkesalahan dalam proses perhitungan zakat dan pembayaran zakat mealui UPZ maupun juru pungut tidak bisa dilakukan setiap saat karena keterbatasan jamkerja. Untuk mengatasi permasalahan tersebut dilakukan penelitian yang bertujuan untuk melayani pembayaran zakatyang dilakukan kapan saja oleh Muzzaki setiap saat tanpa batasan jam kerja dari UPZ dan juru pungut.

Aplikasi Perhitungan Zakat berbasis Android ini dirancang menggunakan Android Studioversi 2.3 .3 sebagai tool pengembangan perangkat lunak (Development Tool). Metode pengembangan sistem menggunakan Waterfall Metodedengan 5 langkah analisis, yaitu (1) reqruiment definition, (2) system and software design, (3) implementation and unit testing, (4) integration and system testing, (5) operation and maintenance.

Penelitian ini menghasilkan Aplikasi PerhitunganZakat Berbasis Android di BAZNAS Kabupaten Karanganyar. Dapat disimpulkan bahwa aplikasi dapat me mberikan kemudahan bagi Muzzakiuntuk menghitung dan membayar zakat kapan saja tanpa batasan waktu jam kerja dari UPZ dan juru pungut, serta tidak terjadi kesalahan penghitungan.
\end{abstract}

Kata kunci-Zakat, Android, UPZ, Muzzaki

\section{Abstract}

The National Amil Zakat Agency (BAZNAS) Karanganyar District in collecting zakat from the community forms a Zakat Collecting Unit (UPZ) and Collectors. The problem faced is errors in the zakat calculation process, payment through UPZ and Collector can not be done anytime due to limited working hours. To Overcome the problem, we do research to serving the zakat payments by Muzzaki that can be done at any time without limitation of working hours.

The Zakat Calculation app based on android is designed using Android Studio 2.3.3 as a software development tool. System development method using waterfall method with 6 steps analysis, that (1) reqruiment definition, (2) system and software design, (3) implementation and unit testing, (4) integration and system testing, (5) operation and maintenance.

The result of this study is The Application of Zakat Counter Based Android on The National Amil Zakat Agency (BAZNAS) Karanganyar District.It can be concluded that the application can make easy for Muzzaki to calculate and pay zakat anytime without limitation of working hours of UPZ and Collector, and no calculation errors occur.

Keywords—Zakat, Android, UPZ, Muzzaki

Received April 3, 2020; Revised April 13, 2020; Accepted December 17, 2020 


\section{PENDAHULUAN}

Zakat merupakan salah satu rukun Islam yang harus dikerjakan oleh umat Islam. Zakat berasal dari bahasa Arab, yang merupakan bentuk kata dari zaka yang berarti "suci", "baik", "berkah", "tumbuh", dan "berkembang". Menurut syara' zakat merupakan nama bagi sejumlah harta tertentu yang telah mencapai syarat tertentu yang diwajibkan oleh Allah untuk dikeluarkan dan diberikan kepada yang berhak menerimanya dengan persyaratan tertentu pula.

Untuk melaksanakan proses penghimpunan zakat dari para muzzaki, BAZNAS Kabupaten Karanganyar telah membentuk Unit Pengumpul Zakat (UPZ) di berbagai Lembaga/Instansi sesuai dengan ketentuan Undang-Undang. Selain UPZ, BAZNAS Kabupaten Karanganyar juga telah mengangkat satu orang juru pungut di semua Desa dan Kelurahan.

Dengan dibentuknya UPZ di Lembaga/Instansi dan juru pungut di semua Desa dan Kelurahan diharapkan capaian penghimpunan zakat dan kesadaran membayar zakat bagi karyawan dan masyarakat menjadi lebih besar. Namun permasalahan yang terjadi adalah tidak semua UPZ dan juru pungut mengetahui tentang tata cara penghitungan zakat. Juru pungut tidak dikenal oleh masyarakat karena cakupan wilayah pelayanan yang cukup luas. Biaya operasional yang dikeluarkan sangat besar karena jumlah UPZ dan juru pungut yang terlalu banyak, terjadinya beberapa kesalahan rekapitulasi pengumpulan zakat oleh juru pungut. UPZ dan juru pungut tidak bisa menyetorkan hasil pengumpulan zakat secara real time karena pembayaran dilakukan secara konvensional yaitu setoran langsung ke BAZNAS Kabupaten Karanganyar atau melalui Bank. UPZ maupun juru pungut tidak bisa melayani pembayaran zakat setiap saat karena keterbatasan jam kerja.

Berdasarkan permasalahan yang terjadi, maka perlu dibuat sebuah aplikasi menggunakan metode waterfall dan Android Studio sebagai tool development sehingga pembayaran zakat dapat dilakukan setiap saat tanpa batasan waktu jam kerja dan tempat.

Dengan dibuat "Aplikasi Perhitungan Zakat Berbasis Android di BAZNAS Kabupaten Karanganyar" membantu UPZ dan juru pungut dalam menghimpun pembayaran zakat setiap saat dan muzzaki terhindar dari kesalahan perhitungan zakat.

\section{METODE PENELITIAN}

Metode penelitian meliputi analisis sistem yang berjalan, arsitektur atau rancangan metode yang digunakan untuk menyelesaikan masalah.

\subsection{Analisis Sistem yang Berjalan}

Badan Amil Zakat Nasional (BAZNAS) Kabupaten Karanganyar dalam memberikan pelayanan pembayaran zakat dengan cara Muzzaki bertemu dan berkonsultasi dengan bidang pengumpulan untuk menghitung apakah harta yang dimiliki sudah memenuhi persyaratan untuk berzakat, apabila harta telah memenuhi persyaratan berzakat maka Muzzaki melakukan pembayaran zakat kepada petugas yang ada dan menerima kwitansi sebagai bukti pembayaran zakat. Untuk flowchartsistem pembayaran zakat yang dilakukan di BAZNAS Kabupaten Karanganyar dapat dilihat pada Gambar 1. 


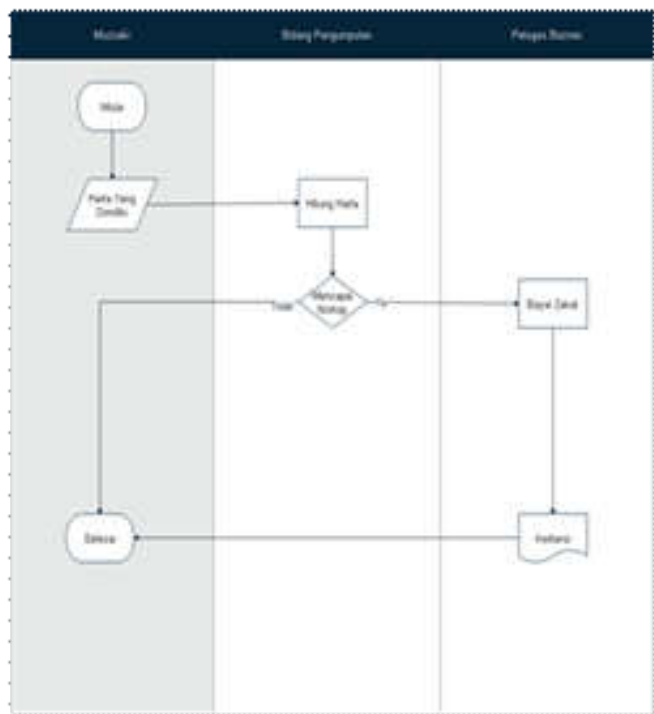

Gambar 1 Flowchart sistem pembayaran zakat di bidang pengumpulan

\subsection{Analisis Sistem}

Alur kerja aplikasi dapat dilihat pada Gambar 2.

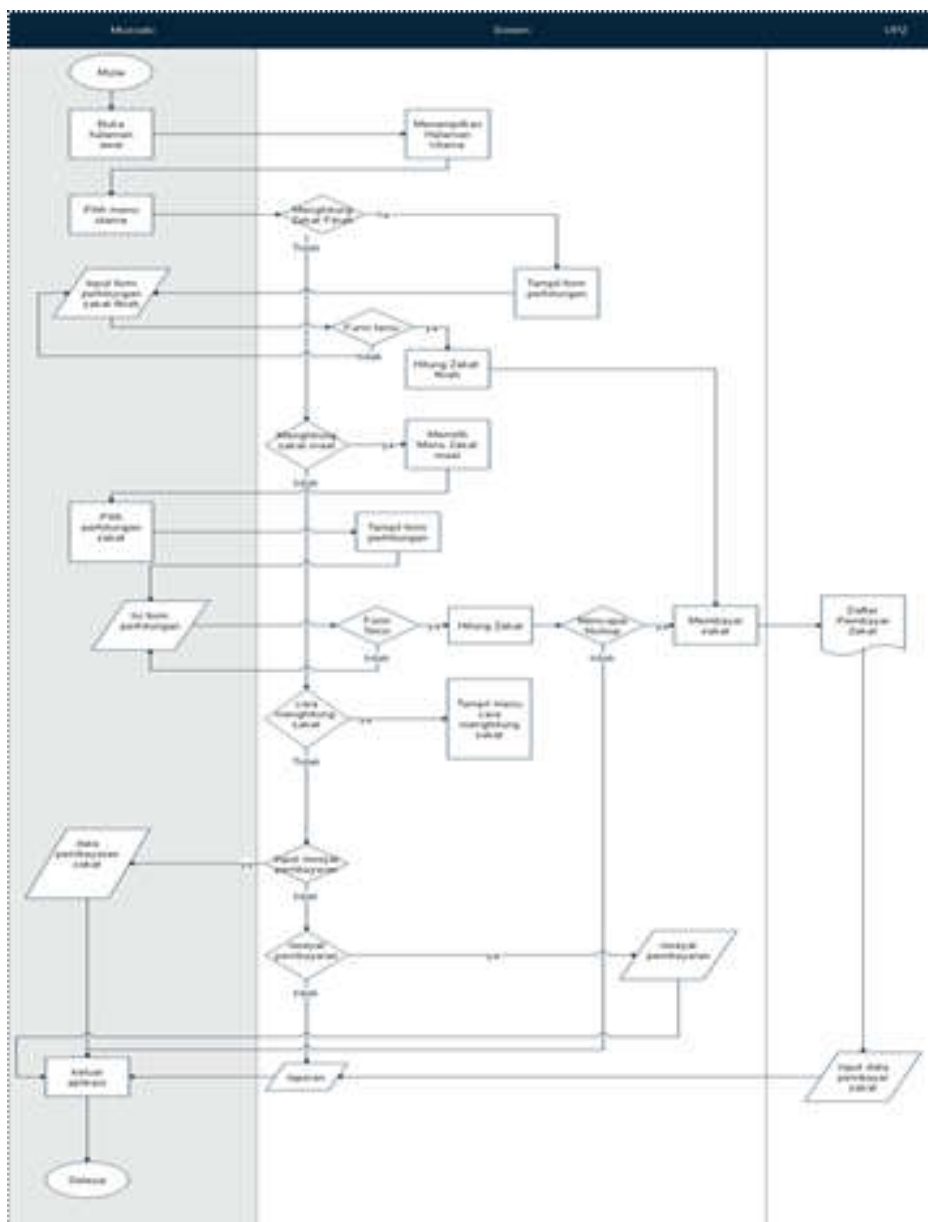

Gambar 2 Flowchart sistem aplikasi 


\subsection{Use Case Diagram}

Use case Diagram Aplikasi Perhitungan BAZNAS Kabupaten Karanganyar dapat dilihat pada Gambar 3.

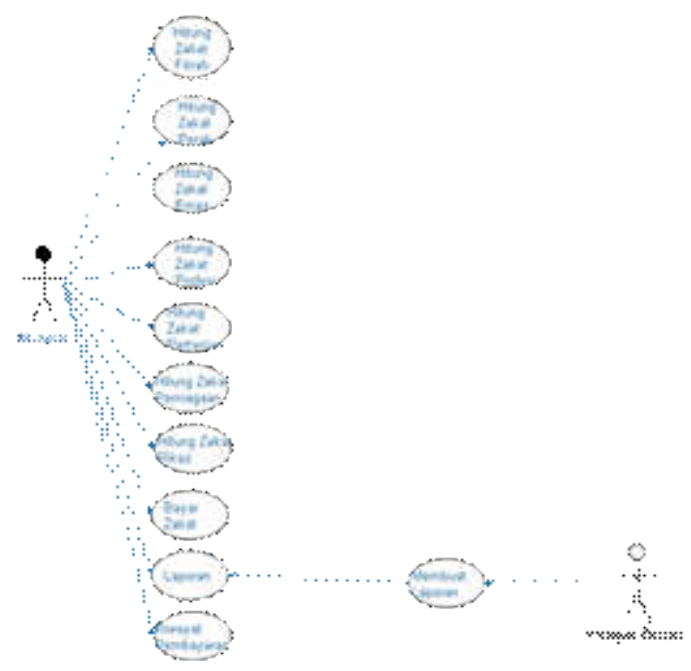

Gambar 3 Usecase diagram aplikasi perhitungan zakat baznaz Kab. Karanganyar

\subsection{Activity Diagram}

Setelah Use case Diagram Aplikasi Perhitungan Zakat Baznas Kabupaten Karanganyar dibuat, maka aktivitas selanjutnya yaitu memodelkan secara grafis dari langkah-langkah setiap aktifitas yang dilakukan ke dalam sebuah Activity Diagram sepertipada Gambar 4.

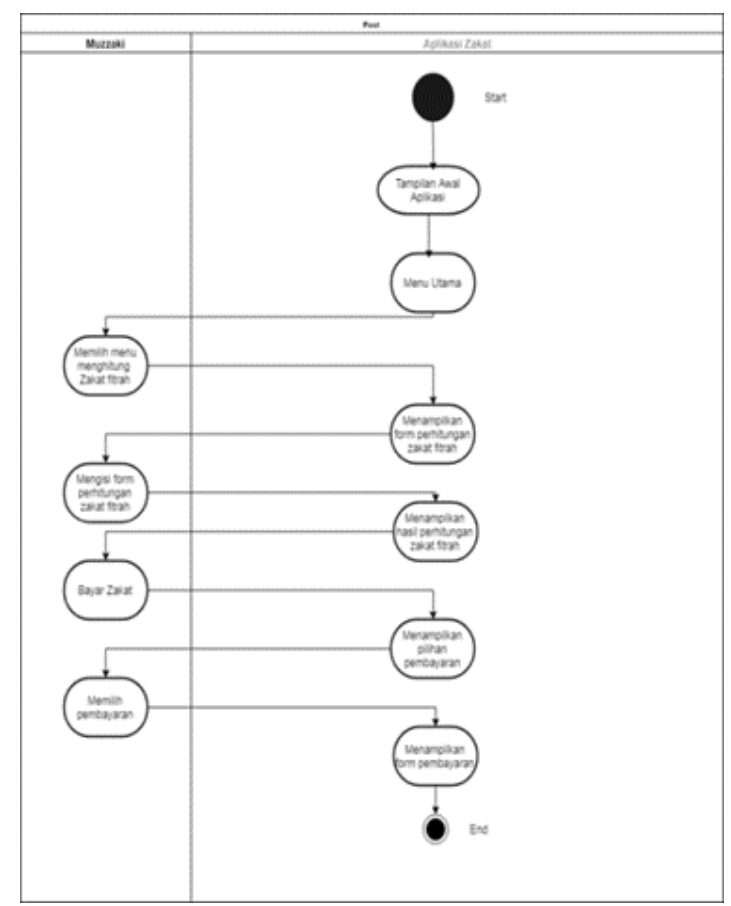

Gambar 4 Activity diagram 


\subsection{Sequence Diagram}

Sequence diagram perhitungan zakat fitrah BAZNAS Kabupaten Karanganyar dapat digambarkan seperti pada Gambar 5.

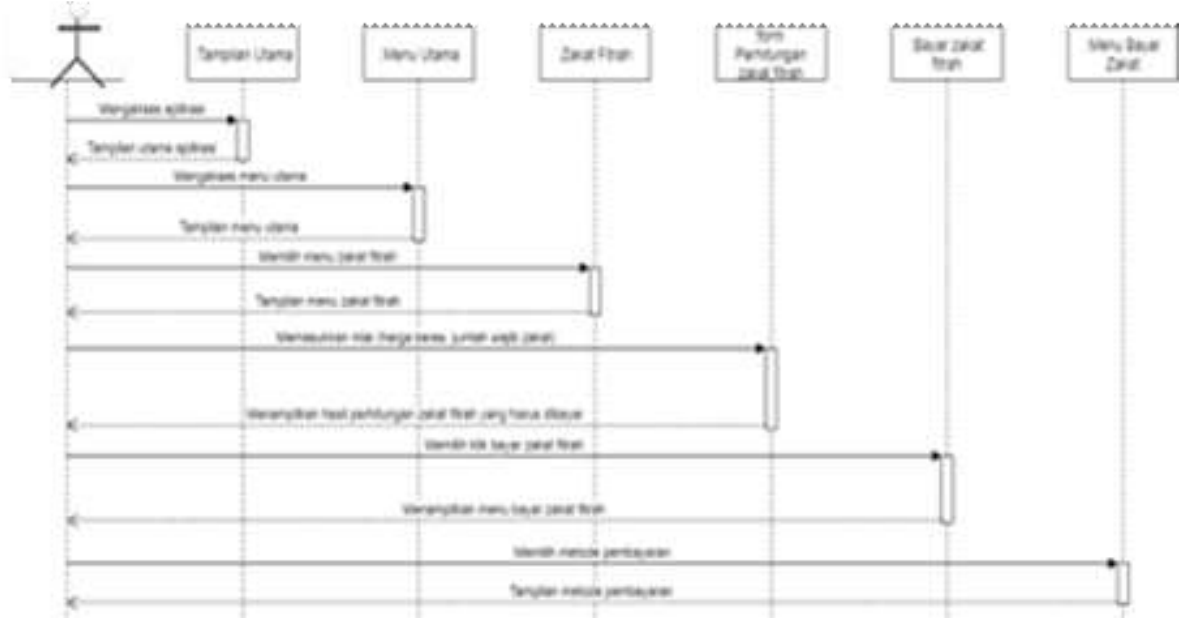

Gambar 5 Sequence diagram perhitungan zakat

\section{HASIL DAN PEMBAHASAN}

\subsection{Halaman Utama}

Pada halaman utama terdapat 3 (tiga) buah menu yaitu menu perhitungan zakat fitrah, menu perhitungan zakat maal, dan menu cara menghitung zakat seperti Gambar 6 .

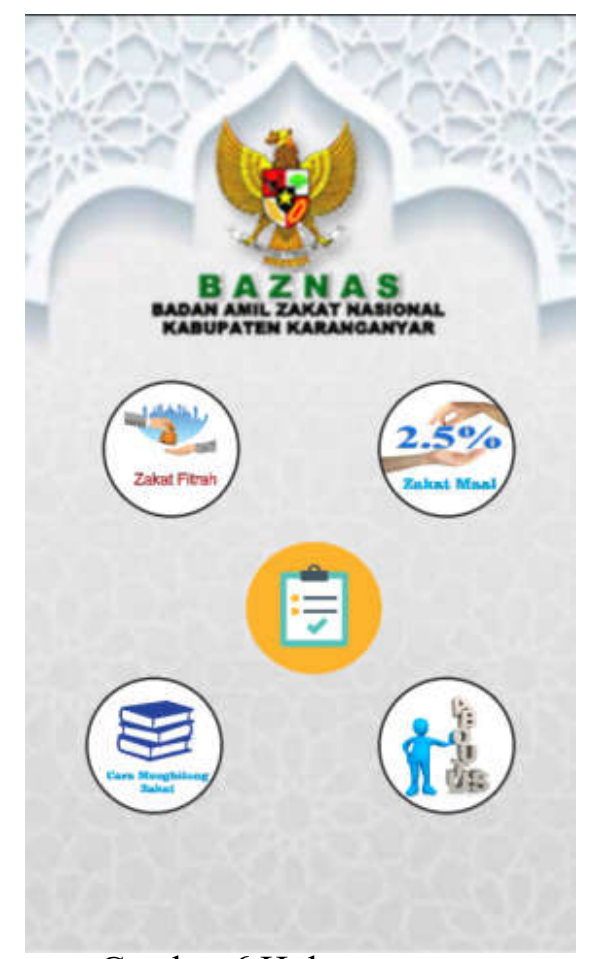

Gambar 6 Halaman utama 


\subsection{Zakat Fitrah}

Halaman menghitung zakat fitrah adalah halaman yang digunakan untuk Perhitungan zakat fitrah. Didalam halaman menghitung zakat fitrah terdapat icon bergambar beras yang berfungsi untuk melakukan update harga beras terkini. Button hitung berfungsi untuk melakukan perhitungan zakat fitrah yang harus dibayarkan berdasarkan hasil inputan dari Muzzaki. Button bayar zakat fitrah berfungsi untuk menghubungkan ke halaman pilihan pembayaran zakat setelah Muzzaki melakukan perhitungan zakat. Button hapus berfungsi untuk menghapus perhitungan yangtelah dilakukan dan button kembali berfungsi untuk kembali ke halaman utama. Halaman zakat fitrah dapat dilihat pada Gambar 7.

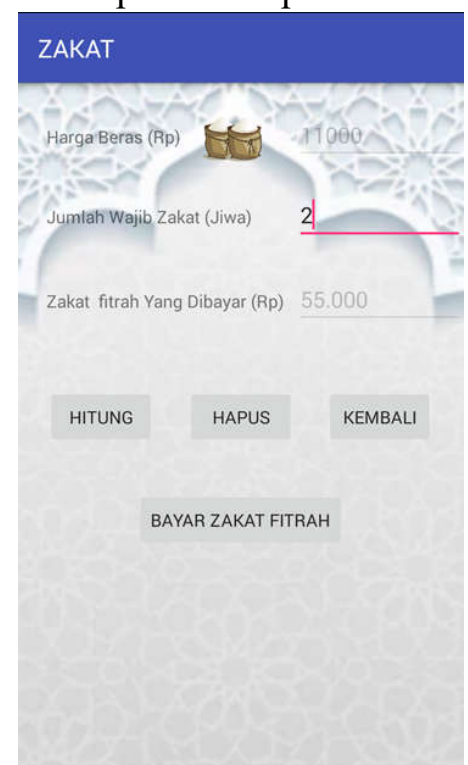

\subsection{Zakat Maal}

Gambar 7 Halaman menghitung zakat fitrah

Halaman zakat maal berisi enam pilihan menu perhitungan zakat maal antara lain zakat perak, zakat emas, zakat profesi, zakat pertanian, zakat perniagaan, dan zakat rikaz. Pilihan menu diwakili dengan gambar masing-masing zakat maal yang akan dihitung. Menu tersebut akan menghubungkan ke masing-masing halaman perhitungan zakat yang dipilih. Tampilan halaman zakat maal dapat dilihat pada Gambar 8 .

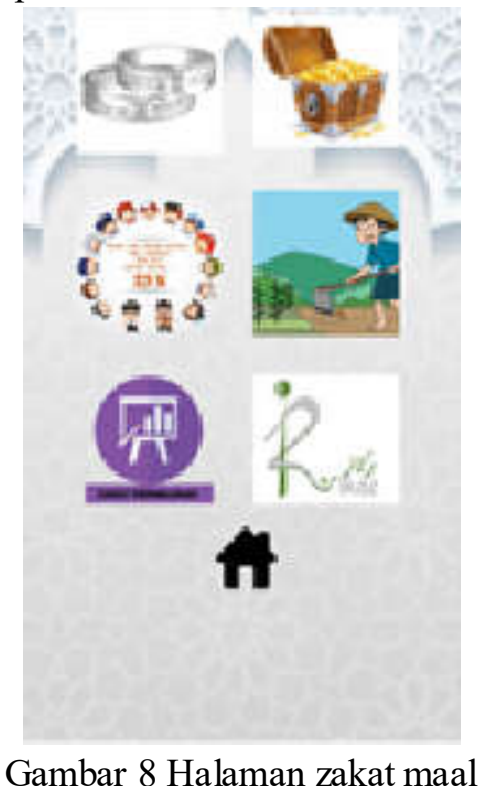

GO INFOTECH: JURNAL ILMIAH STMIKAUB Vol. 26, No. 2, Desember 2020: 107-118 


\subsection{Halaman Menghitung Zakat Perak}

Halaman menghitung zakat perak adalah halaman yang digunakan untuk Perhitungan zakat perak. Halaman menghitung zakat perak terdapat dua buah inputan yang harus diisi oleh Muzzaki untuk menentukan besar zakat perak yang harus dibayar. Tampilan halaman menghitung zakat perak dapat dilihat pada Gambar 9 sebagai berikut :

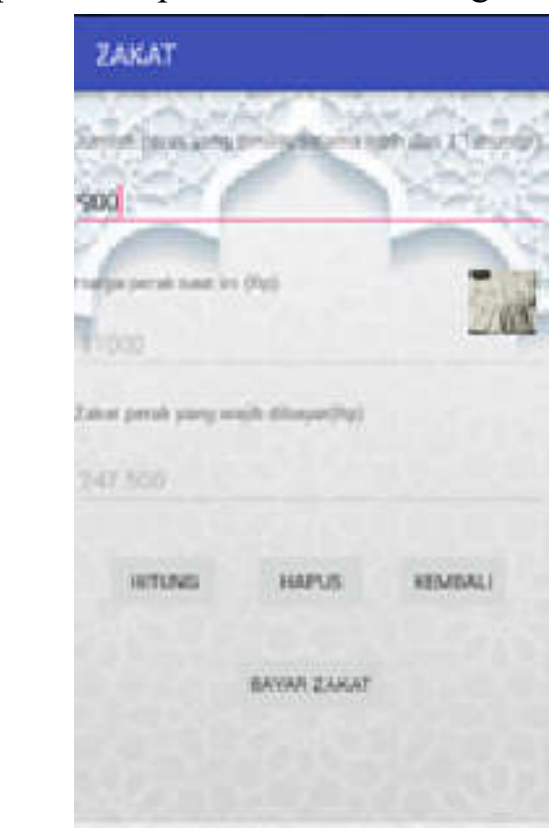

Gambar 9 Halaman menghitung perak

\subsection{Halaman Menghitung Zakat Emas}

Halaman menghitung zakat emas adalah halaman yang digunakan untuk Perhitungan zakat emas. Halaman menghitung zakat emas terdapat dua buah inputan yang harus diisi oleh Muzzaki untuk menentukan besar zakat emas yang harus dibayar. Untuk memasukkan harga emas saat ini terdapat icon bergambar emas yang berfungsi untuk melakukan update harga emas terkini. Tampilan halaman menghitung zakat emas dapat dilihat pada Gambar 10.

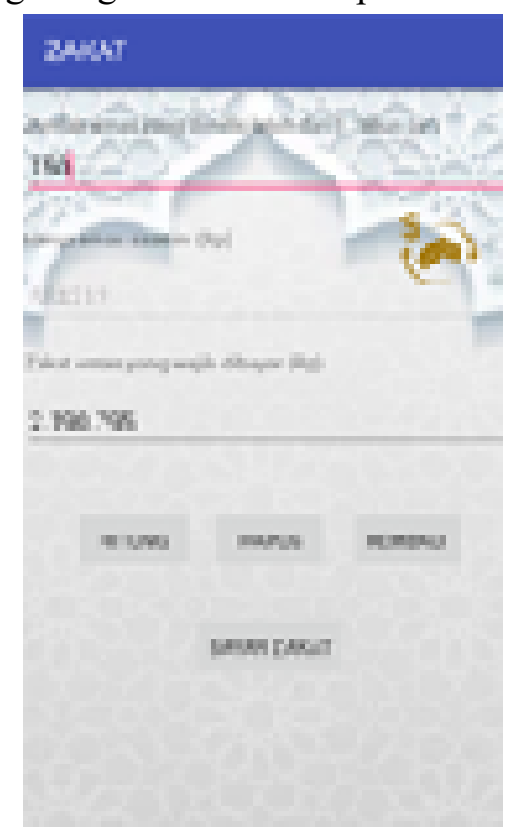

Gambar 10 Halaman menghitung zakat emas 


\subsection{Halaman Menghitung Zakat Profesi}

Halaman menghitung zakat profesi digunakan untuk Perhitungan zakat profesi. Terdapat dua buah inputan yang harus diisi oleh Muzzaki untuk menentukan besar zakat profesi yang wajib dibayar. Inputan yang diisi antara lain pendapatan selama 1 bulan dan harga beras saat ini untuk menentukan besar nishop zakat. Tampilan halaman menghitung zakat profesi dapat dilihat pada Gambar 11 sebagai berikut :

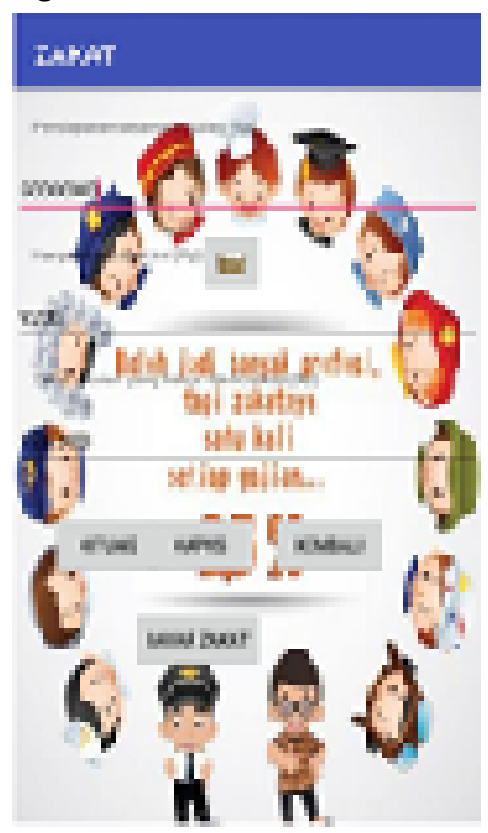

Gambar 11 Halaman menghitung zakat profesi

\subsection{Halaman Menghitung Zakat Pertanian}

Halaman menghitung zakat pertanian digunakan untuk Perhitungan zakat pertanian pada waktu panen. Dalam menentukan nishop zakat pertanian perlu diinputkan harga beras saat ini. Untuk memasukkan harga beras saat ini terdapat icon bergambar beras yang berfungsi untuk melakukan update harga beras terkini. Tampilan halaman menghitung zakat pertanian dapat dilihat pada Gambar 12 sebagai berikut :

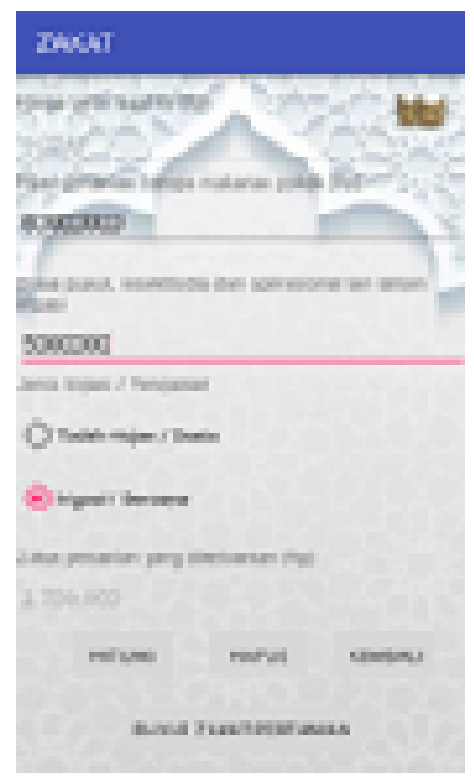

Gambar 12 Halaman menghitung zakat pertanian 


\subsection{Halaman Menghitung Zakat Perniagaan}

Halaman menghitung zakat perniagaan digunakan untuk Perhitungan zakat perniagaan. Dalam menentukan nishop zakat perniagaan perlu diinputkan harga emas saat ini. Untuk memasukkan harga emas saat ini terdapat icon bergambar emas yang berfungsi untuk melakukan update harga emas terkini. Tampilan halaman menghitung zakat perniagaan dapat dilihat pada Gambar 13 sebagai berikut :

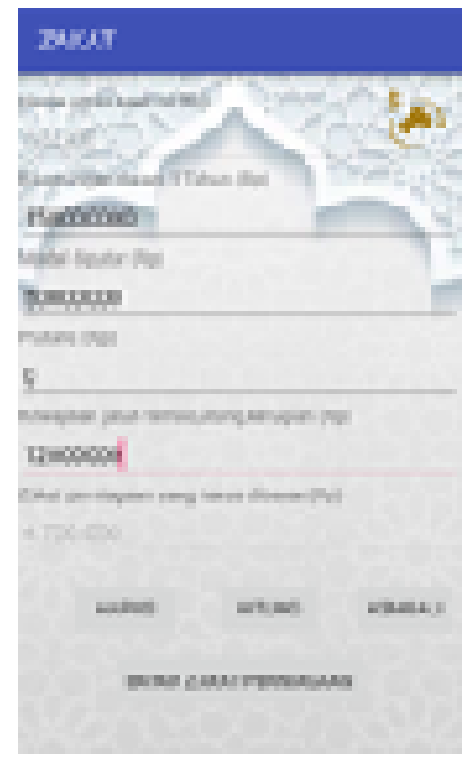

Gambar 13 Halaman menghitung zakat perniagaan

\subsection{Halaman Pembayaran Zakat Melalui Internet Banking}

Halaman pembayaran zakat melalui internet banking berisi jumlah nominal zakat yang harus di bayar dan web site internet banking dari lembaga perbankan. Halaman pembayaran zakat melalui internet banking dapat dilihat pada Gambar 14 sebagai berikut :

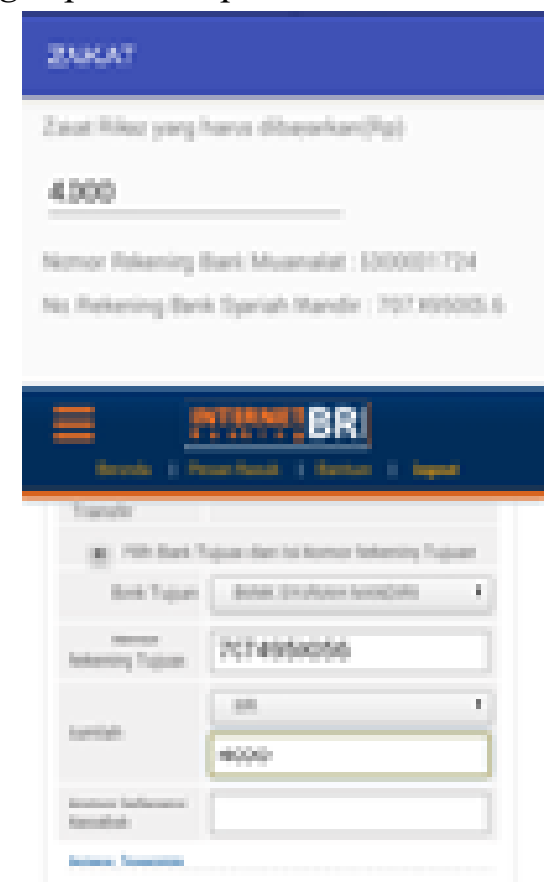

Gambar 14 Halaman pembayaran zakat melalui internet banking 


\subsection{Halaman Pembayaran Zakat Melalui SMS Banking}

Pada halaman pembayaran zakat melalui sms banking terdapat jumlah nominal zakat yang harus dibayarkan. Halaman pembayaran zakat melalui sms banking dapat dilihat pada Gambar 15.

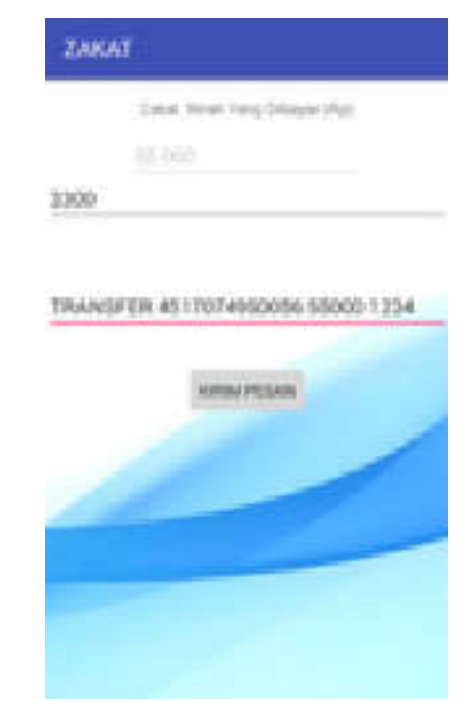

Gambar 15 Halaman pembayaran zakat melalui SMS banking

\section{KESIMPULAN}

Telah dirancang Aplikasi Perhitungan Zakat Berbasis Andorid di Badan Amil Zakat Nasional (BAZNAS) Kabupaten Karanganyar. Berdasarkan hasil penelitian yang telah penulis lakukan, kesimpulan yang didapat adalah sebagai berikut :

1. Perancangan sistem menggunakan pemodelan UML (Unified Modeling Language) dengan komponen yang digunakan yaitu usecase diagram, activity diagram, sequence diagram, dan desain interface. Sistem dibangun menggunakan bahasa pemrograman Java dengan IDE Android Studio 2.3.3. sehingga menghasilkan Aplikasi Perhitungan Zakat Berbasis Android di Badan Amil Zakat Nasional (BAZNAS) Kabupaten Karanganyar.

2. Aplikasi Perhitungan Zakat Berbasis Android di Badan Amil Zakat Nasional (BAZNAS) Kabupaten Karanganyar membantu UPZ, juru pungut dan Muzzaki dalam menghitung besar zakat serta membantu proses pembayaran zakat melalui Internet Banking dan SMS Banking sehingga Muzzaki bisa melakukan pembayaran zakat tanpa batasan waktu.Kesimpulan harus mengindikasikan secara jelas hasil-hasil yang diperoleh dan kelebihan dan kekurangannya.

\section{SARAN}

berikut :

Berdasarkan pada kesimpulan diatas, maka penulis memberikan beberapa saran sebagai

1. Pada menu laporan perlu dikembangkan fitur yang bisa menampilkan laporan berdasarkan bulan pembayaran zakat disertai dengan jumlah perolehan zakatnya. Pada Update harga beras, harga emas dan perak dilakukan secara otomatis dengan $\mathrm{xml}$ format.

2. Untuk penelitian selanjutnya perlu adanya penambahan pada jenis perhitungan zakat maal sehingga menu perhitungan zakat maal lebih lengkap.

3. Perlu adanya penambahan pilihan menu pembayaran melalui indomart, alfamart atau melalui kantor pos. 
4. Laporan pembayaran zakat agar dibuat secara real time. Bagian ini adalah opsional. Apabila ada maka saran-saran berisi saran penelitian lebih lanjut untuk menutup kekurangan penelitian saat ini atau pengembangan dari penelitian yang sudah dilakukan.

\section{DAFTAR PUSTAKA}

[1] A.S, Rosa, M.Shalahudin. 2011. Modul Pembelajaran Rekayasa Perangkat Lunak ( Terstruktur Dan Berorientasi Obyek). Bandung : Modula.

[2] Al Fatta, Hanif. 2007. Analisis dan Perancangan Sistem Informasi. Yogyakarta : Andi

[3] Arifanto, Teguh. 2011. Membuat Interface Aplikasi Android Lebih Keren dengan LWIT. Yogyakarta : Andi Offset

[4] Cholis, Nur. 2013. Aplikasi Perhitungan Zakat Berbasis Android. Skripsi. STIMIK E1 Rahma : Yogyakarta.

[5] Dewi, Marsita. 2013. Pembuatan Situs Web Almamater Perguruan Tinngi Menggunakan PHP dan MySQL. Makalah Tugas Akhir. Universitas Diponegoro : Semarang.

[6] Fadhilah Albani, Ahmad. 2015. Rancang Bangun Aplikasi Haji dan Umrah berbasis Multimedia pada Smartphone Bersistem Operasi Android. Skripsi. Universitas Islam Negeri Syarif Hidayatullah : Jakarta.

[7] Hermawan, S. 2011. "Mudah Membuat Aplikasi Android". Yogyakarta : Adi Offset.

[8] Http://baznas.go.id/panduanzakat diakses pada 10 Agustus 2018.

[9] Http://wikipedia/id.m.wikipedia.org/wiki/Android (sistem operasi) diakses pada 10 Agustus 2018.

[10] Ihsanuddin dkk. 2014. Pengembangan Aplikasi Perhitungan Zakat Berbasis Android. Skripsi. Sekolah Tinggi Teknologi Garut : Bandung.

[11] Janner, Simamarta. 2010. Rek ayasa Perangkat Lunak. yogyakarta : Penerbit Andi.

[12] Kadir, Abdul. 2007. Analisis dan Perancangan Sistem Informasi. Yogyakarta : Andi.

[13] KEMENAG. 2013. Panduan Zakat Praktis. KEMENAG : Jakarta.

[14] Kurnia H. dan Hidayat A. 2008. Panduan Zakat Harta Berkah, Pahala Bertambah. Tangerang:QultumMedia

[15] Lubis, Nuril Huda. 2009. Program Aplikasi Penghitungan Zakat dengan Menggunakan J2SE. Skripsi. Universitas Gunadharma : Jakarta

[16] Muhammad, Yachin. 2011. Aplikasi Perhitungan Zakat Berbasis Android. Skripsi. Teknik Informatika STMIK El Rahma : Yogyakarta.

[17] Pahlevy. 2010. Pengertian Flow Chart dan Definisi Data.

[18] Pratama, Erwin Aditya. 2013. Optimalisasi Pengelolaan Zakat Sebagai Sarana Mencapai Kesejahteraan Sosial (Sebuah Studi di Badan Amil Zakat Kota Semarang).

Skripsi. Universitas Negeri Semarang: Semarang.

[19] Prayitno, Budi. 2006. Optimalisasi Pengelolaan Zakat di Badan Amil Zakat Daerah $(B A Z D A)$. Thesis. Universitas Diponegoro : Semarang.

[20] Rickyanto, Isak ST. 2003. Dasar Pemrograman Berorienasi Objek dengan Java 2 (JDK 1.4). Yogyakarta : Andi.

[21] Rizal, Syamsu, dkk. 2013. Pengembangan Aplikasi Pencarian Lokasi Objek Wisata Terdekat di Kabupaten Garut Berbasis Android. Sekolah Tinggi Teknologi Garut : Bandung.

[22] Safaat, Nazarudin. 2012. Pemrograman Aplikasi Mobile Smartphone dan Tablet PC Berbasis Android. Bandung : Informatika Bandung.

[23] Saputro, A. 2011. Aplikasi dan Arsitektur Android. Surabaya : Putra Jatim.

[24] Tandean, M. 2011. Aplikasi Monitoring Web Server dan Implementasi VNC Remote Server Berbasis Android. Bandung : Politeknik Telkom 
[25] Umam, Muhammad Syaiful. 2014. Aplikasi Perhitungan Zakat Mal Emas Dan Zakat Maal Profesi Berbasis Android pada Ponsel Seluler. Skripsi. Universitas Pembangunan Nasional : Surabaya.

[26] Wahyu, Praditya. 2013. Aplikasi Zakat Mobile Berbasis Android. Naskah Publikasi:Institut Teknologi Telkom Bandung.

[27] Witarto. 2004. Memahami Sistem Informasi. Bandung

[28] Yolanda, Beta. 2017. Aplikasi Tuntunan Sholat Pada Smartphone Berbasis Android. Skripsi. Universitas Lampung : Lampung. 